\title{
COOLING HISTORY OF THE EASTERN SVECOKARELIDES: WHOLE-ROCK AND MICA Rb-Sr AND HORNBLENDE K-Ar AGES IN THE AREAS OF PIHTIPUDAS-IISALMI AND JOROINEN-SULKAVA, FINLAND
}

\author{
UELI HAUDENSCHILD
}

\begin{abstract}
HAUDENSCHILD, UELI, 1990. Cooling history of the eastern Svecokarelides: whole-rock and mica $\mathrm{Rb}-\mathrm{Sr}$ and hornblende $\mathrm{K}-\mathrm{Ar}$ ages in the areas of PihtipudasIisalmi and Joroinen-Sulkava, Finland. Bull. Geol. Soc. Finland, 62, Part 1, 39-59.

$\mathrm{Rb}-\mathrm{Sr}$ age determination on mica and whole-rock samples and $\mathrm{K}-\mathrm{Ar}$ age determination on hornblendes were carried out to get information on the time of metamorphism and early cooling in two Proterozic areas of the Finnish Svecokarelides. In the Joroinen-Sulkava area (southern Finland) a whole-rock isochron of $1812 \pm 45 \mathrm{Ma}$ on metapelitic gneisses reflects the time of amphibolite-facies metamorphism. A $1875 \pm 17 \mathrm{Ma}$ whole-rock isochron on a quartz-diorite of the granulite-facies Pielavesi area (central Finland) may date an earlier high-grade metamorphic event, the low $87 \mathrm{Sr} / 86 \mathrm{Sr}$ initial ratio of 0.7018 can be explained only by a shift or rotation of the isochron postdating its age. The disturbation of the whole-rock system could be related to the 1800-1820Ma metamorphism dated in the Joroinen-Sulkava area. A lower limit for the age of the isochron-shift is given by $1750-1790 \mathrm{Ma}$ biotite ages. The 1800-1820Ma metamorphic event seems to have been weaker in central than in southern Finland while the 1875Ma metamorphism seen in central Finland (Pielavesi) is absent or completely overprinted in the south.

Muscovite $\mathrm{Rb}-\mathrm{Sr}$ and hornblende $\mathrm{K}-\mathrm{Ar}$ ages date the cooling of the areas to about $500^{\circ} \mathrm{C}$. Muscovite ages vary between $1730 \mathrm{Ma}$ and $1770 \mathrm{Ma}$ for different localities. Five fractions of two hornblende samples define an isochron of $1778 \mathrm{Ma}$ on the $40 \mathrm{Ar} / 36 \mathrm{Ar}$ versus $40 \mathrm{~K} / 36 \mathrm{Ar}$ diagram. In one locality (Vieremä) the hornblende ages (1995-2143Ma) are remarkably higher than the age of the muscovite (1828Ma). The hornblende ages were interpreted as having a pre-metamorphic memory, being of Jatulian or late Archean origin. The blocking-temperature for argon in horblende therefore should be somewhat higher than the blocking-temperature of muscovite in respect to the $\mathrm{Rb}-\mathrm{Sr}$ system.
\end{abstract}

Key words: absolute age, $\mathrm{Sr}-\mathrm{Rb}$, whole rock muscovite, $\mathrm{K}-\mathrm{Ar}$, hornblende, isochron, metamorphism, cooling, Proterozoic, Finland.

U. Haudenschild: Abteilung für Isotopengeologie der Universität Bern, Erlachstr. 9a, CH-3000 Berne 12, Switzerland. *Present address: Dept. of Geology, Brown University, Providence R.I. 02912 USA

\section{Introduction}

Different blocking-temperatures of the U-Pb, $\mathrm{K}-\mathrm{Ar}$ and $\mathrm{Rb}-\mathrm{Sr}$ systems in various minerals of the same rock or geological unit have been widely used to evaluate cooling and, presuming the paleothermogradient is known, uplift histories of plutonic and metamorphic terrains (Harper 1967; 
Wagner et al. 1977; Mattinson 1978). The condition for the evaluation of cooling histories according to the ages of different minerals measured by the use of different radiogenic systems is a proper knowledge of the closure temperature of the minerals used, e.g. the temperature at which no radiogenic parent and daughterproducts are lost from the analyzed material by diffusional exchange or reaction. For volume diffusion the effective closure temperature of any mineral has been shown to vary with the effective diffusion radius (typically assumed to be the grain size) and cooling rate (Dodson 1973). Due to the rate of diffusion diminishing with decreasing temperature, the closing will proceed from the center of a mineral to the rim leading to closure profiles as described by Dodson (1986). Closure temperatures and therefore measured ages should be related to the effective diffusion radius (grain size) of the analysed minerals.

The closure temperature of a radiogenic system in a certain mineral has been defined by Dodson (1973) as the temperature present at the time corresponding to the apparent age.

Jäger (1977) used blocking-temperatures of $500^{\circ} \mathrm{C}, 350^{\circ} \mathrm{C}$ and $300^{\circ} \mathrm{C}$ for the $\mathrm{Rb}-\mathrm{Sr}$ system on muscovite, $\mathrm{K}-\mathrm{Ar}$ on muscovite and $\mathrm{K}-\mathrm{Ar}$ on biotite respectively, the blocking-temperture for the $\mathrm{K}-\mathrm{Ar}$ and the $\mathrm{Rb}-\mathrm{Sr}$ systems in biotite being about the same. The closure temperature of the $\mathrm{Rb}-\mathrm{Sr}$ system in alpine biotites has been calculated mathematically (Dodson 1973) assuming that resetting of radiogenic ages is ruled by volume diffusion of the radiogenic daughter isotopes, fitting well with the above mentioned temperature of $300^{\circ} \mathrm{C}$. A possible difficulty in the interpretation of biotite $\mathrm{Rb}-\mathrm{Sr}$ ages has been pointed out recently by Giletti and Farver (1988) and Farver and Giletti (1989). Biotite may be the last Sr-bearing mineral to close in rocks of that composition and therefore, after the closure of the second-last mineral, has no possibility of further ion exchange. In this case, the measured biotite age therefore might be higher than the age corresponding to its effective closure temperature.

In contrast to volume diffusion, reaction of the mineral during metamorphic reheating or slow cooling may reset the age abruptly without leaving any closure profile. The formation of secondary minerals such as sphene or ilmenite in biotite, if formed at temperatures around $300^{\circ} \mathrm{C}$ may be the explanation for the constancy of biotite blocking-temperatures independent of the actual mineral grain size (Jäger pers. comm.). The temperature controlling the age system will then correspond to the lowest temperature at which biotite can react forming Ca-phases which will accept the (radiogenic) strontium, where volume diffusion might occur at even lower temperatures as a superimposed effect. In this connection it might be necessary to define the term closuretemperature as the temperature at which in a given mineral lattice no diffusional exchange of any specific element is possible any more, while the term blocking-temperature refers to the temperature related to the measured mineral age. The terms will be used in this sense within this paper.

Estimates for the blocking-temperature of U$\mathrm{Pb}$ in zircon, sphene and apatite are given by Mattinson (1982) as $>600^{\circ} \mathrm{C}, 450-500^{\circ} \mathrm{C}$ and $400^{\circ} \mathrm{C}$ respectively. The blocking-temperature for $\mathrm{U}-\mathrm{Pb}$ in monazite has been estimated to be about $530^{\circ} \mathrm{C}$ by Wagner et al. (1977), a higher blocking-temperature around $720-750^{\circ} \mathrm{C}$ has been reported by Copeland et al. (1988). Besides the blocking-temperature of any mineral, the temperature during a metamorphic overprint at which the mineral will start losing radiogenic daughter products by diffusional exchange or reaction is of major importance for the interpretation of mineral age data. The temperature of the first lead loss of monazite and also zircon will depend on the conditions of the crystal lattice, e.g. the grade of metamictisation and therefore the uranium content and the age of the mineral. The metamict crystal will lose lead at fairly low temperatures, at which the lattice will be healed. Radiogenic lead thereafter may be accumulated 


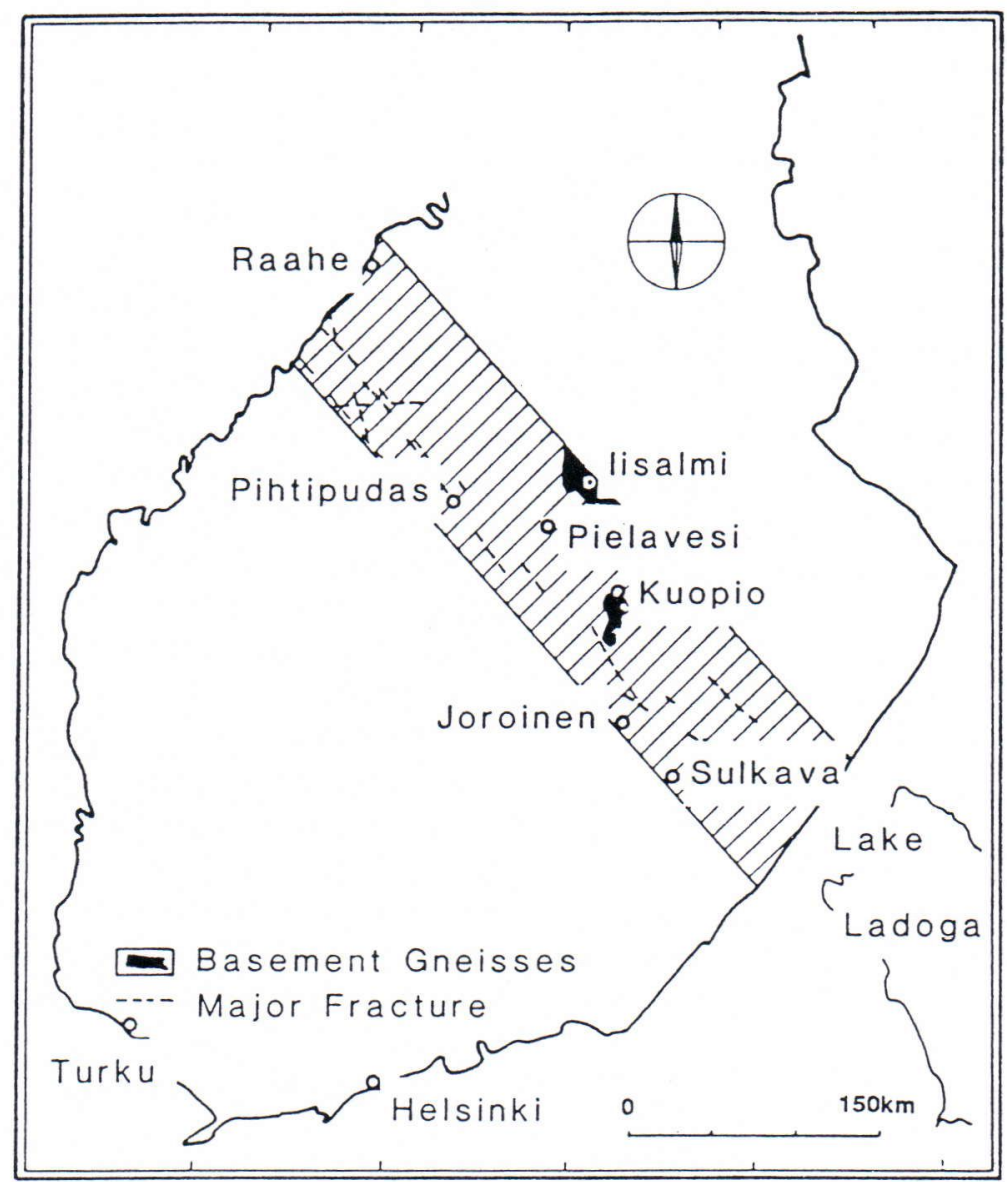

Fig. 1. Map of Southern Finland showing the main sulphide ore belt (after Neuvonen et al. 1981) and the localities used in the text.

again even at rising temperatures. If the metamorphism reaches a temperature at which the undisturbed crystal opens, the isotopic age will define the cooling to the temperature where lead is accumulated again. If low-grade metamorphic temperatures do not allow the undisturbed crystal to open, the time of the first healing will be registered. A third possibility is the formation of monazite and especially sphene during metamorphism. If minerals form below their blocking-temperature, the age determined would represent a formation age.

The blocking temperature for amphiboles as well as its ruling parameters are still controver- sial. A higher argon retention by hornblende than by biotite has been described in contact metamorphic terrains analyzing host rock minerals at different distances from the contact (Hart 1964, Hanson and Gast 1967). Differences in the blocking temperature of blue amphibole and hornblende have been recognized by Coleman and Lanphere (1971). Harrison (1981) suggested hornblende blocking temperatures between $490-550^{\circ} \mathrm{C}$. Dallmeyer and Rivers (1983) used $500^{\circ} \mathrm{C}$ as blocking temperature to interprete their hornblende data. McDowell et al. (1984) proposed a temperature of $350^{\circ} \mathrm{C}$ for the retention of argon in glaucophane. Onstott and Peacock 
(1987) proposed differences in the $\mathrm{Fe} /(\mathrm{Fe}+$ $\mathrm{Mg}+\mathrm{Mn}$ ) ratio as the reason for different blocking temperatures although Harrison (1981) states that »diffusity of argon in hornblende is not sensitive to its $\mathrm{Fe} / \mathrm{Mg}$ ratio»».

Besides their chemistry, the microstructure of amphiboles seems to be another parameter causing differences in their blocking temperatures. Small lamellae of some $\mu \mathrm{m}$ width of hornblende with intergrown cummingtonite (Harrison 1986) as well as phyllosilicate inclusions of the same order of size (Onstott and Peacock 1987) might provide paths for enhanced argon diffusion rates, thus affecting the effective diffusion radius and therefore the blocking-temperature of hornblende. Onstott and Peacock (1987) calculated blocking temperatures of $412-451^{\circ} \mathrm{C}$ using the width of the lamellae- and $503-562^{\circ} \mathrm{C}$ using the grain size as distance of diffusion, a temperature corresponding well with a temperature of $580^{\circ} \mathrm{C}$ proposed by Harrison (1981), speaking for a reaction more than a volume diffusion process ruling the reset of the radiogenic age.

The present study aimed at forming a model for the evolution and cooling history of the Svecokarelidic orogenesis on the base of radiogenic age determination using the above mentioned methods on plutonic and metamorphic rocks of two different areas of Central Finland.

A number of K-Ar biotite and muscovite ages of the areas of Pihtipudas-Vaaraslahti-Iisalmi and Joroinen-Sulkava have been published previously (Korsman et al. 1984, Haudenschild 1988b) giving a differentiated picture of the cooling to $300^{\circ} \mathrm{C}$. Zircon, monazite and sphene $\mathrm{U}-\mathrm{Pb}$ ages were available for the area of Pihtipudas (Aho 1979) dating the age of the intrusion of synorogenic plutonic rocks and their metamorphic overprint. Additional U-Pb ages were published for both areas (Salli 1983; Korsman et al. 1984; Vaasjoki and Sakko 1988). Age data of bordering areas (Gorkov et al. 1970; Lehtovaara 1972; A. Huhma 1981; H. Huhma 1986; Paavola 1986) helped a lot in understanding the events dated in context with the large scale events of the Svecokarelic orogenesis.

\section{Summary of geology}

The Pihtipudas-Iisalmi and Joroinen-Sulkava areas lie within the eastern part of the Svecokarelian units, close to the Raahe-Ladoga schist zone (Marttila 1976), or the so-called main sulphide ore-belt (Neuvonen et al. 1981) (Fig. 1) crossing Finland NW-SE from the northern end of the Baltic sea to lake Ladoga, thought to represent the suture line between Svecokarelic orogenic rocks and the Archean basement (Korsman 1988).

Lithologically they are composed mainly of basic- to intermediate metavolcanic and intercalated metapelitic rocks and synorogenic dioritic to tonalitic gneissic intrusives. The grade of metamorphism varies from lower amphibolite to granulite facies. The two areas show some lithological similarities, although their metamorphism »differs in both type and time» (Hölttä 1988).

Both areas are crossed by deep-seated fault systems trending NW-SE through Finland, of which the Kinturi-fault (Fig. 2) has been shown extending to the moho (Hölttä 1988). Four different directions of tectonic lineaments were described in the area of Tervo (Pajunen 1986) south of Pielavesi, leading to the formation of a mosaic-like structure of the crust (Härme 1961).

The Pihtipudas-Iisalmi region has been described in detail by Aho (1979), Marttila (1976), Salli (1983), Korsman et al. (1984) and Hölttä (1988). It can be devided into six blocks of different metamorphic overprint (Hölttä 1988), from west to east: Pihtipudas, Korppinen, Pielavesi, Osmanki, Lampaanjärvi, Vieremä, partly separated by fault-lines, the Vieremä block bordering the Archean basement in the east (Fig. 2). The western margin of the Lampaanjärvi block has been contact-metamorphically overprinted by a suite of pyroxene bearing granitic to monzonitic intrusions (Vaaraslahti intrusive). 


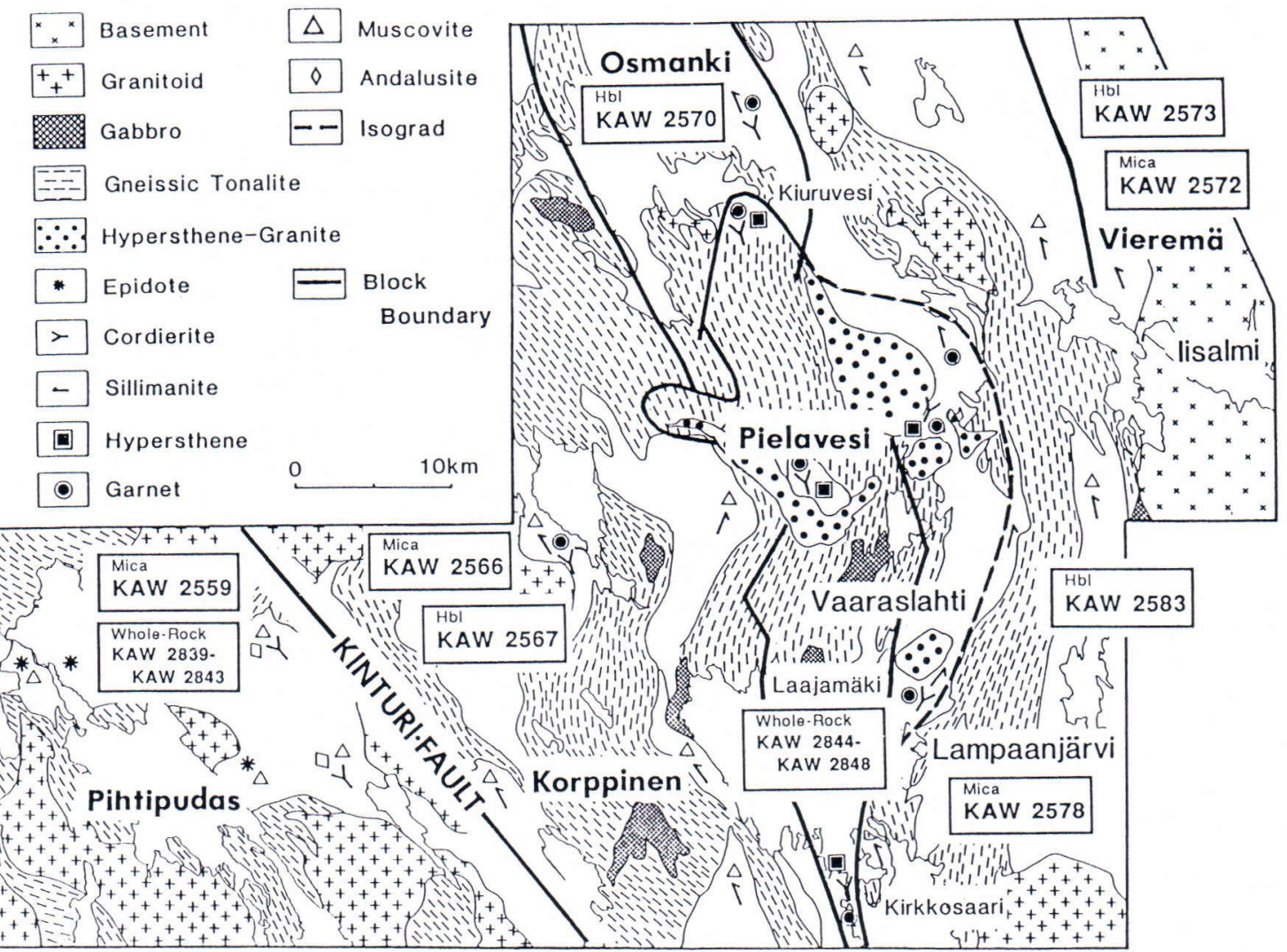

Fig. 2. Tectono-metamorphic map of the Pihtipudas-Iisalmi area (after Hölttä 1988) showing the sample localities.

The overprint can be mapped by the aid of different isograds (Hölttä 1988), having lead to a rise in temperature from the stability field of muscovite outside the contact-metamorphic influence, to granulite facies conditions at the immediate contact to the granite. Besides their differences in metamorphism, the different blocks can be distinguished by different lithologies corresponding to formation and overprint in different levels of the crust therefore having had different uplift histories, being brought to juxtaposition about 1600Ma ago (Haudenschild 1988b).

Detailed investigation of the Joroinen-Sulkava area were carried out by Gaal and Rauhamäki (1971), Paavola (1976), Korsman (1977) and
Korsman et al. (1984). Progressive metamorphism increasing from north to south is explained by the surface dipping slightly towards the north (Korsman 1977), the temperature having been lowest (lower amphibolite facies) in Rantasalmi, increasing towards the south to granulite facies conditions. The forming of a thermal dome in the southern part of the area (Sulkava) lead to a rise in temperature at isostatic conditions, causing partial melting of the pelitic rocks and the formation of a migmatitic potassiumfeldspar granite. An increase in the metamorphic conditions was also observed between Rantasalmi and the northern Joroinen-zone, muscovite being stable in Rantasalmi, while sillimanite is stable with potassium-feldspar around Joroinen. 


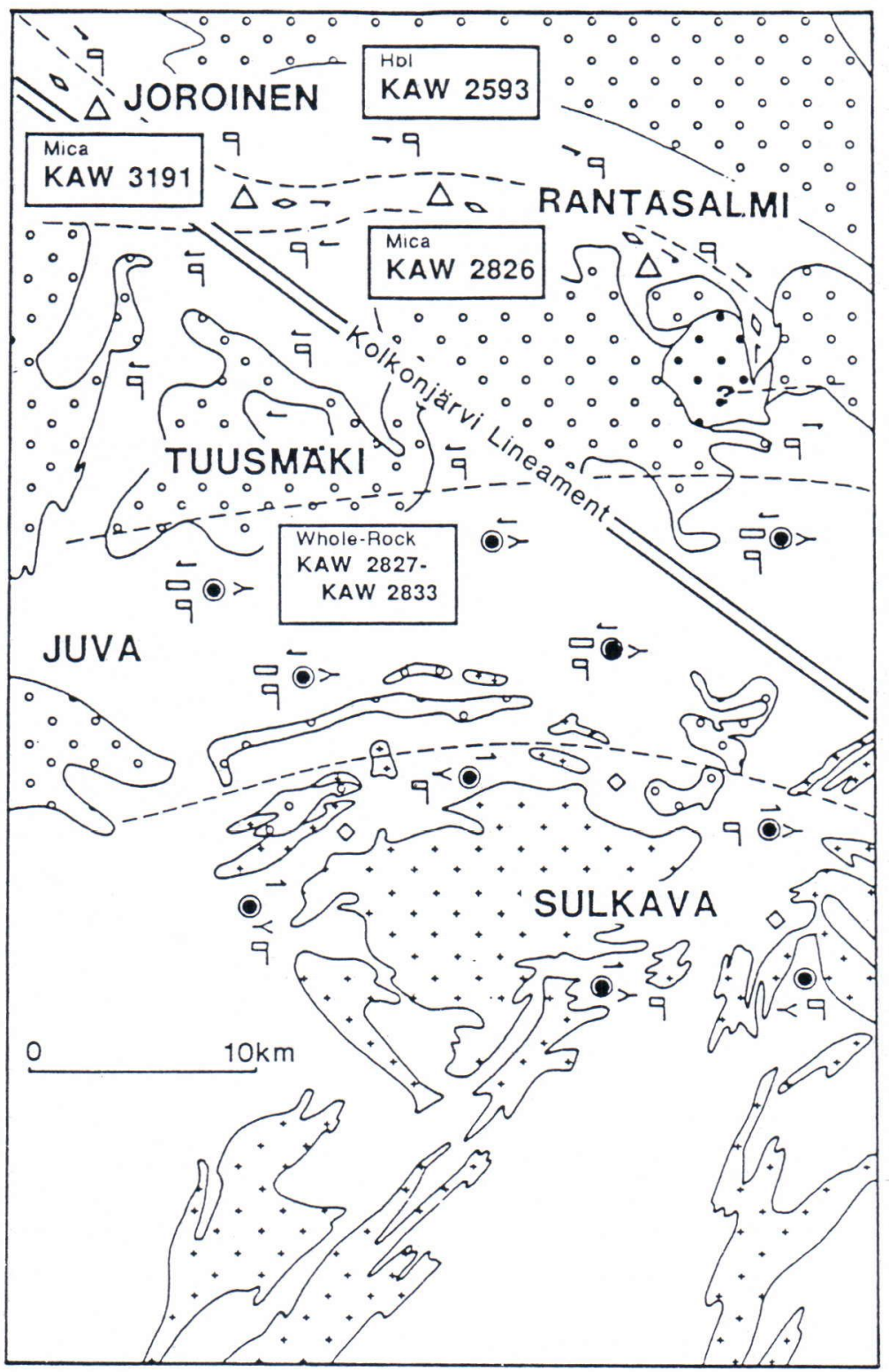

\begin{tabular}{|c|c|c|c|}
\hline$\bullet^{\circ}$ & Diorite and Gabbro & $-\infty \Delta$ & Andalusite/Muscovite \\
\hline $0^{\circ}$ & Tonalite & ב & Sillimanite/K-Feldspar \\
\hline . & Granite & - & Biotite/Cordierite \\
\hline-- & Isograd & $0 / 0$ & Garnet/Hypersthene \\
\hline
\end{tabular}

Fig. 3. Metamorphic map of the Joroinen-Sulkava area (after Korsman et al. 1984) showing the sample localities. 


\section{Methods}

\section{Sampling}

$30 \mathrm{~kg}$ samples were collected for all $\mathrm{Rb}-\mathrm{Sr}$ whole-rock analysis. Fresh hand specimens were taken for mineral age analysis whenever possible, otherwise, a coredriller was used to take several fresh drill-cores. The sample size varies between $5-10 \mathrm{~kg}$ for hammer-taken samples an around $2 \mathrm{~kg}$ for drill-cores.

The whole-rock samples of Juva could be taken from fresh roadcuts, those of Pihtipudas from an active quarry. For the samples of the Laajamäki gneiss blasting was necessary to get fresh material.

\section{Separation technique and chemical treatment}

All samples were crushed, milled and split. The split taken for every whole-rock analysis was $100 \mathrm{ml}$. For mineral separation the samples were sieved to grain-size fractions of $>30,30-60$, $60-80,80-120$ mesh. Micas were separated with the aid of a magnetic separator, milled five minutes in an agate mortar under ethanol abs., sieved, and whenever necessary purified on the magnetic separator again.

Hornblende samples were preconcentrated on a magnetic separator and a shaking table and finally concentrated with the aid of heavy liquids (bromoforme). Whole-rock samples were milled for 16 to 24 hours in an agate mortar under ethanol abs.

The samples were dissolved in a perchlorichydrofluoric acid mixture. Rb-Sr samples were spiked with highly concentrated ${ }^{84} \mathrm{Sr}$ and ${ }^{87} \mathrm{Rb}$ spike. $\mathrm{Rb}$ and $\mathrm{Sr}$ were separated on ion-exchange colomns. Potassium samples were spiked with a ${ }^{40} \mathrm{~K}$ solution $\left(35,927 \%{ }^{40} \mathrm{~K}\right)$.

\section{Measurements}

Argon measurements were carried out on a VG MM1200 mass-spectrometer. Analyses were done according to the ID method (Kirsten 1966, Dal- rymple and Lanphere 1969). Samples were packed in aluminum foil and molten in a molybdenum crucible, using a high-frequency generator, in a high-vacuum extraction line (Flisch 1986). The extracted gas was spiked with a $99,99975{ }^{38} \mathrm{Ar}$ spike (Schumacher 1975) purified and transferred to the mass-spectrometer by a direct connection. Biotite B-4B and LP-6 (Flisch 1982) were used as standard minerals.

Rubidium and potassium were measured on a solid source single collector mass spectrometer made by $»$ Ion Equipements» with $35 \mathrm{~cm}$ radius and a three-filament ion source, where the sample was loaded onto the centre filament and evaporated by heating only the side filaments simultanously.

Strontium analyses were done partly on the »Ion Equipment» instrument partly on a VG Sector mass-spectrometer with $26 \mathrm{~cm}$ radius, five collectors and a single filament ion source. The differences in the ${ }^{87} \mathrm{Sr} /{ }^{86} \mathrm{Sr}$ between the two machines was $<15 \mathrm{ppm}$. The ages were calculated using the IUGS constants (Steiger and Jäger 1977).

The mica analyses were corrected using the initial ${ }^{87} \mathrm{Sr} /{ }^{86} \mathrm{Sr}$ ratio of the corresponding whole rock isochron (see below). For all metapelite and micaschist samples a ${ }^{87} \mathrm{Sr} /{ }^{86} \mathrm{Sr}$ ratio of 0.707 was used. For the augen-gneiss of Lampaanjärvi a ${ }^{87} \mathrm{Sr} /{ }^{86} \mathrm{Sr}$ initial of 0.7039 was used, given for the synorogenic granodiorites by Welin et al. (1980). According to the low ${ }^{87} \mathrm{Sr} /{ }^{86} \mathrm{Sr}$ ratio of most of the white mica samples (below 10), the ratio used for the correction is of major influence to the mica age result. A difference of 5 in the fourth decimal of the initial used will shift the white mica age considerably $(0.7075$ instead of 0.7070 used for the white micas of Pihtipudas will lower the age about $10 \mathrm{Ma}$ ). The cooling rates calculated using the white mica $\mathrm{Rb}-\mathrm{Sr}$ determinations will therefore always give a hint on the relative cooling in relation to the cooling calculated for lower temperatures (Haudenschild 1988b) but never can be taken as absolute values. The age difference between different grain-size fractions differs up 
to $35 \mathrm{Ma}$ demonstrating the actual error of the calculated ages.

\section{Analytical results}

\section{Hornblende data}

Sample description

Five samples were taken for K-Ar dating of hornblendes. All samples were collected from amphibolite rocks nearly or completely free of biotite. The samples have been chosen from different metamorphic blocks of the PihtipudasIisalmi (Fig. 2) and the Joroinen-Sulkava areas (Fig. 3) near to localities from where biotite and, whenever possible, muscovite had been dated (Haudenschild 1988b). In this way the hornblende results should be easily comparable with the mica ages without interpolation of ages between localities. All localities are given in Figs. 2/3.

Sample KAW 2567 was taken from a banded amphibolite of the Korppinen block only about $1 \mathrm{~km}$ north of the micaschist (KAW 2566, Haudenschild 1988b) taken for mica dating. The fresh fine grained sample taken by the aid of a core-driller is very dark and, viewed in hand specimen, completely homogeneous. The rock consists of $45-50 \%$ hornblende $0.2-0.3 \mathrm{~mm}$ in size, $50 \%$ plagioclase, some quartz, apatite, zircon, sphene and opaques. The minerals are homogeneously distributed, the hornblende is orientated in the direction of the banding. The sample is fresh, the hornblende practically free of inclusions.

KAW 2570 is a homogeneous medium grained metadiorite. It crops out about $2.5 \mathrm{~km}$ southwest of the nearest metapelite outcrop having been sampled for biotite dating (Haudenschild 1988b). Its composition is: hornblende $60 \%$, plagioclase $30-40 \%$, quartz $5 \%$, some biotite, opaques, apatite and zircon. The long (up to $2 \mathrm{~mm}$ ) biotite needles are ductile, slightly deformed and often cross the hornblende crystals.
KAW 2573 is a greenish amphibolite. It was taken from the zone of Vieremä, close to the sample KAW 2572 (Haudenschild 1988b) from which biotite and muscovite have been dated. The weathered surface shows a yellowish-grey groundmass with homogeneously distributed, unoriented amphibole needles of about $2 \mathrm{~mm}$ length. Microscopically the hornblende (45$50 \%$ ) shows a garben-like texture, is slightly poikiloblastic enclosing epidote, plagioclase, and opaques. Plagioclase, showing a slight sericitisation, is at $50 \%$ the other main constituent.

KAW 2583 is a sample of the metavolcanic comlex of Lampaanjärvi lying close to the sample profile taken for $\mathrm{K}$-Ar biotite dating (Haudenschild 1988b). The rock is a banded amphibolite of varying composition. Its main minerals are hornblende (50-55\%), plagioclase (40\%), quartz, potassium feldspar, cummingtonite, epidote, diopside, sphene and carbonate. Some biotite is orientated in the direction of the banding. The hornblende margins are partly replaced by cummingtonite and epidote, epidote is also a common inclusion. Usually hornblende, cummingtonite, epidote and sphene built up a net-like texture with sericitised feldspar grains distributed in between. From the microscopic observation cummingtonite and hornblende probably cannot be separated.

KAW 2593 comes from the zone of Joroinen. Samples for apatite fission track dating were taken from the same locality (Torsalo) by Lehtovaara (1972). In the fine-grained dark green amphibolites, garnets up to some $\mathrm{mm}$ in size can be seen macroscopically. The garnet is strongly piokiloblastic. Hornblende (50\%), plagioclase and cummingtonite are the main constituents of the rock; quartz, apatite and opaques are the accessories. Some small biotite flakes are enclosed by the hornblende. The feldspar is slightly sericitised, green hornblende shows grain margins of cummingtonite.

Age results

Samples KAW 2567, 2570, 2583 and 2593 be- 
long to the Svecocarelian units, sample KAW 2573 was taken from the Vieremä schist zone, lying between the metavolcanic complex of Kiuruvesi-Lampaanjärvi (Marttila 1976) and the Archean basement of Iisalmi. The age results are listed in table 1.

The ages of the Svecokarelic hornblende samples vary between 1350Ma and 1784Ma. Samples 2567 (Korppinen) and 2583 (Lampaanjärvi) plot in the »Harper» diagram (Harper 1970), which assumes the same proportion of argon loss for cogenetic samples, on an isochron (Fig. 4) corresponding to an age of $1784 \mathrm{Ma}$ intersecting the $\mathrm{y}$-axis at 0.027 . Without sample KAW 2583i the intersection point is 0.004 . The influence of sample $2583 \mathrm{i}$ in the ${ }^{40} \mathrm{~K} /{ }^{36} \mathrm{Ar} »$ diagram (Fig. 5) is even larger: with this sample the regression line crosses the y-axis at -720.5 ; without, at 329 . The isochron age of $1778 \mathrm{Ma}$ corresponds within the limit of the analytical error to the one of the »Harper» diagram. 2583i has an age of 1695Ma. It is the largest grain size fraction of the sample and shows the highest potassium content. The simplest explanation of the low age is a slight impurity of the sample due to intergrowth with some biotite, increasing the potassium content and lowering the age. Another explanation would be argon loss at low temperature (retrograde reactions ?) in the rim of the mineral. The smaller grainsizes being produced partly by mechanical abrasion during separation represent a higher core/rim ration than the large grains which grainsize is close to the original, containing a larger amount of argon-poor material. The isochron age of $1784 \mathrm{Ma}$ seems to be a good fit to a hornblende cooling age giving the time of cooling to $500-$ $550^{\circ} \mathrm{C}$ after the metamorphic overprint, the $2 \sigma$ error on each age measurement being about $\pm 30 \mathrm{Ma}$.

The ages of samples KAW 2593 and KAW 2570 are clearly lower then those mentioned above, though they should date the same Svecokarelic event. The ages of the two grain size fractions of KAW 2570 are $1544 \mathrm{Ma}$ and $1545 \mathrm{Ma}$ respectively, those of KAW 2593 1404Ma,
$1404 \mathrm{Ma}$ and $1350 \mathrm{Ma}$. Both samples seem to have lost argon below their blocking-temperature. In both diagrams (Fig. 6/7) the isochrons intersect the $y$-axis at negative values. The corresponding isochron ages are $1660 \mathrm{Ma}$ and $2035 \mathrm{Ma}$. The high isochron age in the »Harper» diagram can be explained by a larger amount of argon lost from sample KAW 2593 than KAW 2570, turning the isochron towards a steeper slope. The isochron in the ${ }^{40} \mathrm{~K} /{ }^{36} \mathrm{Ar} »$ diagram is turned in the opposite direction by different amounts of air argon, mixed to the two samples, being larger in sample 2593 than in the other one.

The ages of sample KAW 2573 (1995Ma$2143 \mathrm{Ma}$ ) are too high to correspond to the cooling of the Svecokarelian metamorphism. Excess or inherited argon must be responsible for the ages calculated. Argon incorporated during the metamorphic growth of the amphiboles could explain the »Harper» diagram (Fig. 8). The isochron in the ${ }^{40} \mathrm{~K} /{ }^{36} \mathrm{Ar} »$ diagram (Fig. 9) should show a similar trend, e.g., should have an intersect with the y-axis higher then the argon air ratio. Different amount of argon of identical isotope composition lost from the three grain size fractions of sample 2573 could explain the picture given in both diagrams, the »isochron» of the ${ }^{40} \mathrm{~K} /{ }^{36} \mathrm{Ar} »$ diagram being smoothed by air argon varying in amount between the three fractions. The ages calculated are believed to be mixture ages between the formation and the Svecokarelic overprint. The isochron age given by the $\gg^{40} \mathrm{~K} /{ }^{36} \mathrm{Ar} »$ of $2101 \mathrm{Ma}$ can be considered a minimum age of the hornblende samples; the formation therefore has to belong to a PreSvecokarelian event.

Two hornblende samples published by Korsman et al. (1984) plot, together with the samples KAW 2567 and KAW 2583, on an isochron of $1760 \mathrm{Ma}$ in the $»$ Harper» diagram (Fig. 10). The intersection point with the y-axis is 0.001 . The isochron shows, within the analytical error, a good age estimate for all Svecokarelic hornblende samples independent of their later uplift history evaluated by the mica ages. One can consider the 


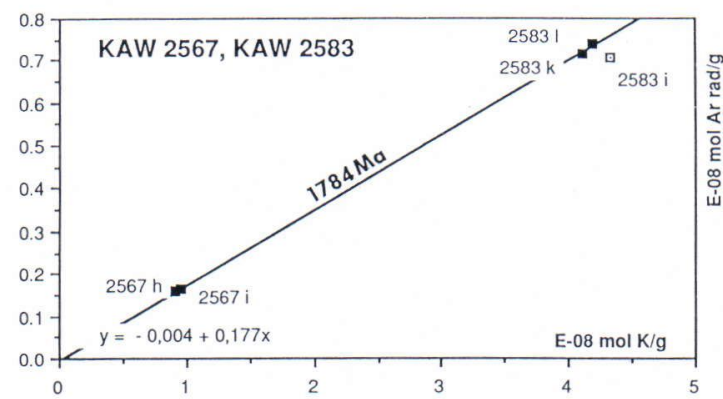

Fig. 4. ${ }^{40} \mathrm{Ar}_{\text {rad }} / \mathrm{g}$ versus ${ }^{40} \mathrm{~K} / \mathrm{g}$ diagram for hornblende samples KAW 2567 and KAW 2583.

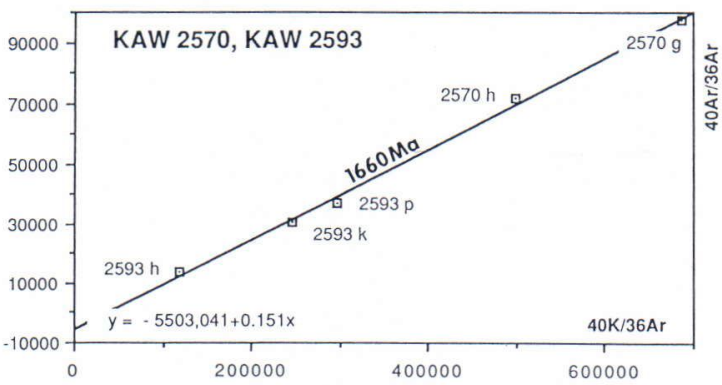

Fig. 6. ${ }^{40} \mathrm{Ar} /{ }^{36} \mathrm{Ar}$ versus ${ }^{40} \mathrm{~K} /{ }^{36} \mathrm{Ar}$ diagram for hornblende samples KAW 2570 and KAW 2593.

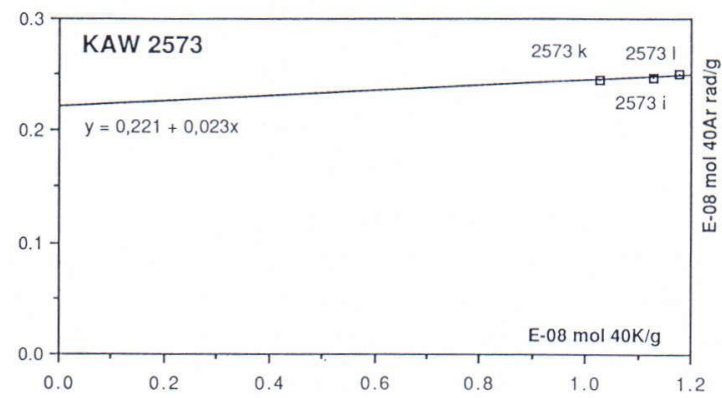

Fig. 8. ${ }^{40} \mathrm{Ar}_{\mathrm{rad}} / \mathrm{g}$ versus ${ }^{40} \mathrm{~K} / \mathrm{g}$ diagram for hornblende samples KAW 2573.

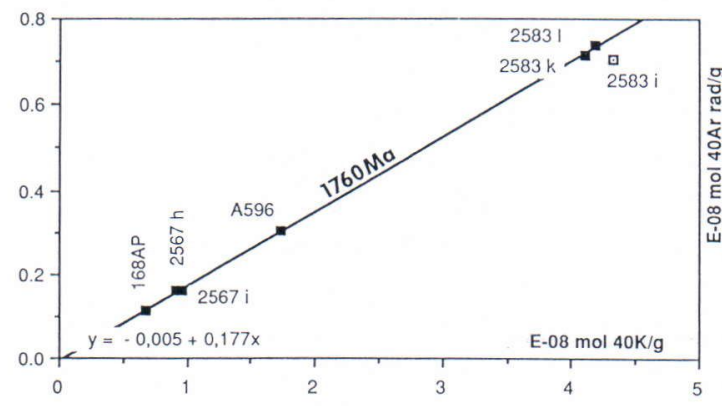

Fig. 10. ${ }^{40} \mathrm{Ar}_{\mathrm{rad}} / \mathrm{g}$ versus ${ }^{40} \mathrm{~K} / \mathrm{g}$ diagram for Svecokarelian hornblende samples (A596 and 168AP: Korsman et al. 1984).

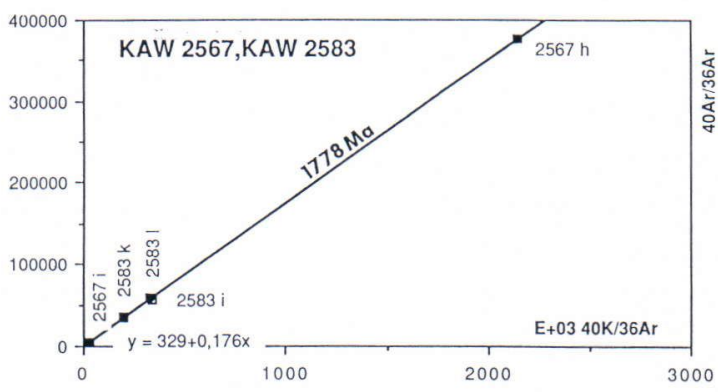

Fig. 5. ${ }^{40} \mathrm{Ar} /{ }^{36} \mathrm{Ar}$ versus ${ }^{40} \mathrm{~K} /{ }^{36} \mathrm{Ar}$ diagram for hornblende samples KAW 2567 and KAW 2583.

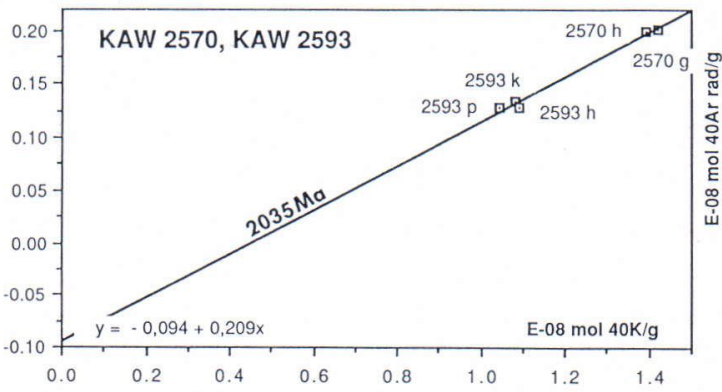

Fig. 7. ${ }^{40} \mathrm{Ar}_{\text {rad }} / \mathrm{g}$ versus ${ }^{40} \mathrm{~K} / \mathrm{g}$ diagram for hornblende samples KAW 2570 and KAW 2593.

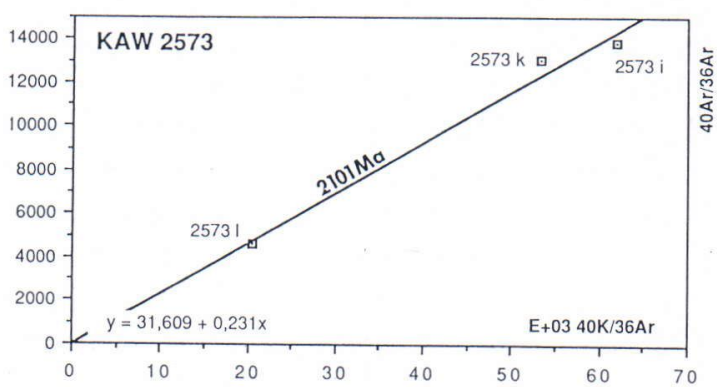

Fig. 9. ${ }^{40} \mathrm{Ar} /{ }^{36} \mathrm{Ar}$ versus ${ }^{40} \mathrm{~K} /{ }^{36} \mathrm{Ar}$ diagram for hornblende samples KAW 2573.

cooling after an 1810Ma metamorphism a largescale event having reached the blocking-temperature for amphibole at approximatly the same time in Korppinen, Lampaanjärvi and Tuusmäki. Age differences showing differences in the uplift speed of the various blocks cannot be recognized, the analytical error, mainly caused by impurities of the hornblende concentrates (inclusions), being too large. 
Table 1. Sample locations and isotopic data for hornblende K-Ar results.

\begin{tabular}{|c|c|c|c|c|c|c|}
\hline $\begin{array}{l}\text { Sample } \\
\text { KAW No. }\end{array}$ & Locality & $\begin{array}{l}\text { Grain Size } \\
\text { (mesh) }\end{array}$ & $\% \mathrm{~K}$ & $\begin{array}{c}\text { Vol }{ }^{40} \mathrm{Ar}_{\text {rad. }} \\
\mathrm{ccmSTP} / \mathrm{g} \times 10^{-4}\end{array}$ & $\%{ }^{40} \mathrm{Ar}$ & Age (Ma) \\
\hline $2567 \mathrm{~h}$ & Kumpuskangas/Korppinen & $80-100$ & 0.307 & 0.3603 & 99.92 & 1774 \\
\hline $2567 \mathrm{i}$ & Kumpuskangas/Korppinen & $100-120$ & 0.319 & 0.3624 & 93.85 & 1739 \\
\hline $2570 \mathrm{~g}$ & Palosuo/Osmanki & $80-100$ & 0.476 & 0.4523 & 99.70 & 1545 \\
\hline $2570 \mathrm{~h}$ & Palosuo/Osmanki & $100-120$ & 0.466 & 0.4470 & 99.59 & 1554 \\
\hline $2573 \mathrm{i}$ & Kettukangas/Vieremä & $60-80$ & 0.378 & 0.5528 & 97.86 & 2032 \\
\hline $2573 \mathrm{k}$ & Kettukangas/Vieremä & $80-100$ & 0.344 & 0.5505 & 97.73 & 2143 \\
\hline 25731 & Kettukangas/Vieremä & $100-120$ & 0.395 & 0.5593 & 93.65 & 1995 \\
\hline $2583 \mathrm{i}$ & Syrjälä/Lampaanjärvi & $60-80$ & 1.447 & 1.5813 & 99.47 & 1695 \\
\hline $2583 \mathrm{k}$ & Syrjälä/Lampaanjärvi & $80-100$ & 1.374 & 1.6025 & 99.16 & 1767 \\
\hline 25831 & Syrjälä/Lampaanjärvi & $100-120$ & 1.400 & 1.6572 & 99.50 & 1784 \\
\hline $2593 \mathrm{~h}$ & Tornioniemi/Joroinen & $100-120$ & 0.366 & 0.2856 & 97.91 & 1350 \\
\hline $2593 \mathrm{k}$ & Tornioniemi/Joroinen & $100-120$ & 0.362 & 0.2987 & 99.04 & 1404 \\
\hline $2593 \mathrm{p}$ & Tornioniemi/Joroinen & $80-100$ & 0.349 & 0.2883 & 99.20 & 1404 \\
\hline
\end{tabular}

\section{Rb-Sr mica data}

$\mathrm{Rb}-\mathrm{Sr}$ analysis were carried out on five white mica samples, four from the Pihtipudas-Iisalmi and two from the Joroinen-Sulkava area. The primary idea was to obtain some information about the cooling history of the areas at elevated temperatures in addition to the information on the late uplift history, revealed by $\mathrm{K}-\mathrm{Ar}$ dating (Haudenschild 1988b). A second purpose was to reanalyze two grain size fractions of one single sample of Lampaanjärvi augen-gneiss yielding $\mathrm{K}$ Ar ages one youger and one older then the biotite age, having been interpreted as a cooling age in the case of the older and a formation age in case of the younger age. Finally, the results were thought, compared with the hornblende ages, giving a hint on the hornblende blocking-temperature under the mentioned conditions. Results and sample localities are summarized in table 2 .

Sample KAW 2559 was taken from the low amphibolite metamorphic terrain of Pihtipudas. The K-Ar biotite ages are $1694 \mathrm{Ma} / 1699 \mathrm{Ma}$, the white mica ages $1744 \mathrm{Ma} / 1757 \mathrm{Ma}$. The $\mathrm{Rb}-\mathrm{Sr}$ ages of white mica samples are $1729 \mathrm{Ma}$ and $1763 \mathrm{Ma}$. The maximum temperature of the metamorphism probably has been about $550^{\circ} \mathrm{C}$ at about $1880 \mathrm{Ma}$, only slightly above the blocking-temperature of the white mica. A second overprint of the area may be dated with $1800 \mathrm{Ma}$ by monazite and sphene U-Pb ages (Aho 1979), altough the temperatures involved are difficult to estimate. The white mica results are regarded as reflecting cooling ages. Cooling and related uplift therefore must have been very slow during the early period $(1880-1750 \mathrm{Ma})$ becoming faster towards lower temperatuers, an effect which can also be seen in the K-Ar biotite age pattern (Haudenschild 1988b).

The differences between $\mathrm{K}-\mathrm{Ar}$ and $\mathrm{Rb}-\mathrm{Sr}$ ages in the Korppinen (KAW 2566) and Lampaanjärvi (KAW 2578) block are somewhat larger than the above mentioned, the Rb-Sr ages being $1708 \mathrm{Ma}$ / $1733 \mathrm{Ma}$ in Korppinen and $1732 \mathrm{Ma} / 1751 \mathrm{Ma}$ in Lampaanjärvi. In agreement with the higher metamorphic temperatures, both age determinations are also younger than those made on the Pihtipudas samples having passed the $500^{\circ} \mathrm{C}$ isotherm later than the Pihtipudas mica schists. The mean age difference between $\mathrm{Rb}-\mathrm{Sr}$ and $\mathrm{K}$ Ar determinations are $28 \mathrm{Ma}$ in Korppinen and $91 \mathrm{Ma}$ in Lampaanjärvi. The two grain size fractions of the Lampaanjärvi sample permit the calculation of an isochron corresponding to an age 
of $1715 \mathrm{Ma}$. The age difference calculated above would then be reduced to $65 \mathrm{Ma}$.

The K-Ar age differences described for two grain size fractions of white mica (Haudenschild $1988 \mathrm{~b}$ ) could not be found in the Rb-Sr determinations. The K-Ar ages of 1611Ma and 1650Ma are one lower and one higher than the biotite ages of $1714 \mathrm{Ma} / 1724 \mathrm{Ma}$ indicating a formation age for the smaller grain size fraction. The $\mathrm{Rb}-\mathrm{Sr}$ ages, both lying remarkably higher than the KAr ages contradict this interpretation. The lower $\mathrm{K}$-Ar age of the smaller fraction may be due to argon loss during a late movement.

White mica of samples KAW 2572 (Vieremä) yield a Rb-Sr age of $1829 \mathrm{Ma}$. The K-Ar age of the same sample was $1747 \mathrm{Ma}$, on biotite $1687 \mathrm{Ma} /$ $1696 \mathrm{Ma}$. The result may be interpreted as a formation age, or a cooling age lying close to the peak conditions of metamorphism. The $500^{\circ} \mathrm{C}$ and $350^{\circ} \mathrm{C}$ blocking temperatures permit the calculation of a cooling rate of about $1.8^{\circ} \mathrm{C} / \mathrm{Ma}$.

Two white mica samples could be analyzed from the Joroinen-Sulkava area. Sample KAW
2826 was taken from the Rantasalmi micaschist zone. The Rb-Sr age is $1775 \mathrm{Ma}$. The difference between the $\mathrm{Rb}-\mathrm{Sr}$ and $\mathrm{K}-\mathrm{Ar}$ ages is about the same as that in the mica schists of Pihtipudas, showing similar uplift characteristics. Sample KAW 3191 was taken from the same zone representing large size muscovite of a berylliumpegmatite. The Rb-Sr age is remarkably lower than the age of the mica schist sample. The sample was taken from surface muscovites, the possibility of a slight weathering exists. If the age represents the age of emplacement, the pegmatite would have been intruded to the rock which had been cooled to about $300^{\circ} \mathrm{C}$, the pegmatites deformation still being younger.

\section{$\mathrm{Rb}$-Sr whole-rock ages}

Five mica-schist (metapelite) samples from the block of Pihtipudas have been collected from two quarries over a distance of about $1000 \mathrm{~m}$. The corresponding sample taken for mica dating is KAW 2559. The five whole-rock analysis plot on an

Table 2. Sample locations and isotopic data for the muscovite Rb-Sr analysis.

\begin{tabular}{|c|c|c|c|c|c|c|c|}
\hline $\begin{array}{l}\text { Sample } \\
\text { KAW No. }\end{array}$ & Locality & $\begin{array}{c}\text { Grain Size } \\
\text { (mesh) }\end{array}$ & $\begin{array}{l}\text { Rb total } \\
\text { (ppm) }\end{array}$ & $\begin{array}{l}\text { Sr total } \\
\text { (ppm) }\end{array}$ & ${ }^{87} \mathrm{Rb} /{ }^{86} \mathrm{Sr}$ & $\begin{array}{l}{ }^{87} \mathrm{Sr} / 86 \mathrm{Sr} \\
\text { analytical } \\
\text { error }(1 \sigma)\end{array}$ & Age (Ma) \\
\hline $2559 \mathrm{f}$ & $\begin{array}{l}\text { Kivilouhos/ } \\
\text { Virkamäki }\end{array}$ & $80-100$ & 171.21 & 115.02 & 4.35210 & $\begin{array}{l}0.815349 \\
0.0019^{b}\end{array}$ & 1732 \\
\hline $2559 \mathrm{~s}$ & & $100-120$ & 166.99 & 113.58 & 4.17651 & $\begin{array}{l}0.813101 \\
0.000084^{\mathrm{a}}\end{array}$ & 1767 \\
\hline $2566 \mathrm{k}$ & $\begin{array}{l}\text { Karkeisvuori/ } \\
\text { Korppinen }\end{array}$ & $80-100$ & 72.54 & 22.71 & 9.45107 & $\begin{array}{l}0.939011 \\
0.0022^{\mathrm{b}}\end{array}$ & 1708 \\
\hline 25661 & & $100-120$ & 72.43 & 22.49 & 9.28387 & $\begin{array}{l}0.938341 \\
0.000068^{\mathrm{a}}\end{array}$ & 1733 \\
\hline $2572 \mathrm{~m}$ & $\begin{array}{l}\text { Kiviniemi/ } \\
\text { Vieremä }\end{array}$ & $100-120$ & 196.43 & 87.02 & 6.64216 & $\begin{array}{l}0.881809 \\
0.0011^{\mathrm{b}}\end{array}$ & 1828 \\
\hline 25781 & $\begin{array}{l}\text { Likosuo } \\
\text { Lampaanjärvi }\end{array}$ & $60-100$ & 336.88 & 23.11 & 46.9838 & $\begin{array}{l}1.872920 \\
0.0019^{b}\end{array}$ & 1732 \\
\hline $2578 \mathrm{n}$ & & $130-200$ & 316.78 & 43.47 & 22.2286 & $\begin{array}{l}1.262662 \\
0.0017^{b}\end{array}$ & 1751 \\
\hline $2826 \mathrm{k}$ & Rantasalmi & $80-100$ & 216.04 & 37.40 & 17.4395 & $\begin{array}{l}1.152042 \\
0.0026^{\mathrm{b}}\end{array}$ & 1775 \\
\hline 3191 & $\begin{array}{l}\text { Rantasalmi/ } \\
\text { Pegmatite }\end{array}$ & & 1624.67 & 12.670 & 3408.63 & $\begin{array}{l}84.40284 \\
0.0085^{b}\end{array}$ & 1708 \\
\hline
\end{tabular}

a Relative standard deviation (sample measured on Avco mass spectrometer)

b $\%$ standard error (sample measured on VG sector mass spectrometer) 
isochron of $1704 \pm 42 \mathrm{Ma}$ (Fig. 11). The isotopic data are given in table 3 . The initial ${ }^{87} \mathrm{Sr} /{ }^{86} \mathrm{Sr}$ ratio is 0.7072 . The isochron age of the schists consisting mainly of biotite clearly represents the biotite $\mathrm{Rb}$-Sr age. The corresponding $\mathrm{K}$-Ar ages are $1699 \mathrm{Ma}$ and $1694 \mathrm{Ma}$. The whole-rock age is a good proof of the validity of the K-Ar ages.

Five fresh whole-rock samples were taken from the Laajamäki quartz-diorite (Pielavesi-block) by blasting. Biotite and zircon ages were analyzed on sample KAW 2351, previously taken from the same rock (Haudenschild 1988b, Vaasjoki and Sakko 1988). The whole-rock isochron (Fig. 12) defines an age of $1875 \mathrm{Ma}$ with a remarkably small error of $\pm 17 \mathrm{Ma}$ altough the spread of the ${ }^{87} \mathrm{Rb} /{ }^{86} \mathrm{Sr}$ ratio between the five samples is below 1.0. The initial ${ }^{87} \mathrm{Sr} /{ }^{86} \mathrm{Sr}$ ratio of the isochron is 0.7018 . Despite the good fit of all five samples, the isochron is believed to be shifted and possibly rotated towards the low initial $\mathrm{Sr}$ ratio measured. The shift has to postdate the isochron age, a minimum age for the overprint shifting the isochron is given by the biotite $\mathrm{K}$-Ar age of about $1760 \mathrm{Ma}-1790 \mathrm{Ma}$ (Haudenschild 1988b). Weather the $1875 \mathrm{Ma}$ whole-rock age can be considered to represent a geological event or is caused by rotation of the isochron as described by Åberg and Persson (1984) cannot be answered definitively. After Van Schmus and Bickford (in: Åberg and Persson 1984) a rotation up to $20 \%$ away from the original age is possible, still giving a good fit of all samples. The good fit to the isochron is a hint to the stable platform behaviour of the area after its $1800 \mathrm{Ma}$ events, the disturbed young isochron being flattened by a long time of undisturbed aggregation of radiogenic strontium.

Seven samples of metapelitic rocks of the Juva zone (Joroinen-Sulkava area) plot on an isochron of $1812 \pm 46 \mathrm{Ma}$ (Fig.13). The ${ }^{87} \mathrm{Sr} /{ }^{86} \mathrm{Sr}$ initial value is 0.707 . The samples were taken from roadcuts over a distance of about $4.5 \mathrm{~km}$ along the main road between Savonlinna and Juva. The whole-rock isochron age corresponds well with the age of metamorphism dated at $1810 \mathrm{Ma} /$ $1833 \mathrm{Ma}$ by $\mathrm{U}-\mathrm{Pb}$ zircon ages of the migmatite

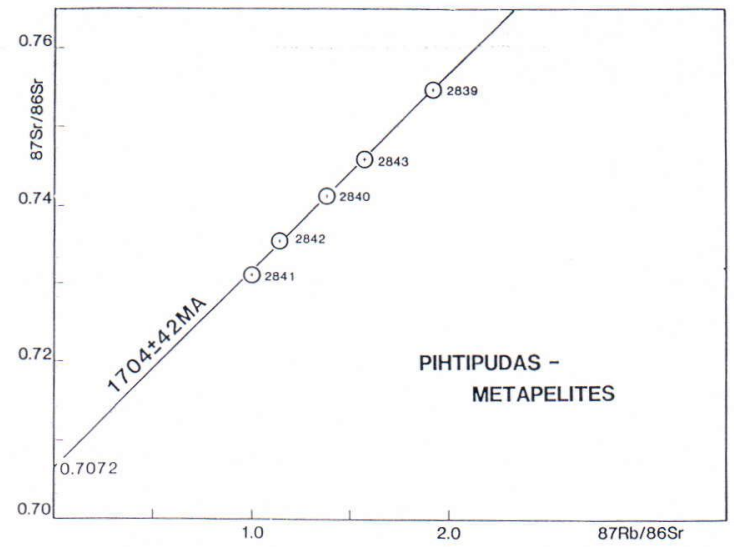

Fig. 11. Whole-rock isochron for the Pihtipudas andalusitebiotite-schists.

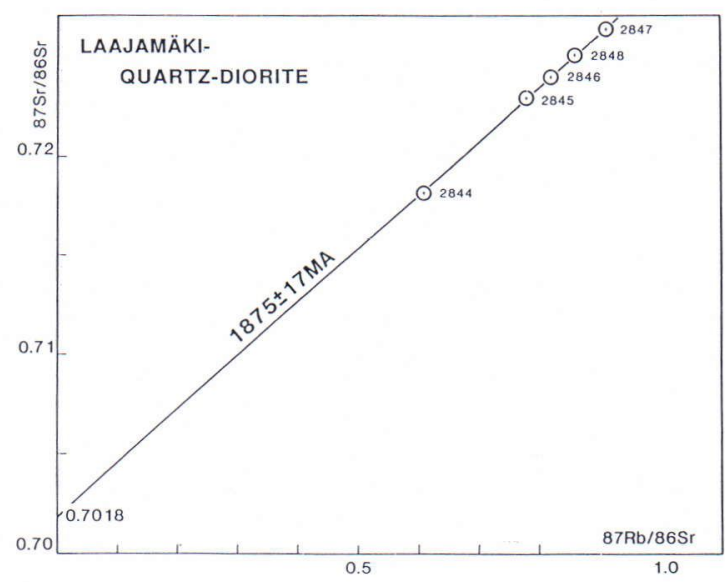

Fig. 12. Whole-rock isochron for the Laajamäki quartz-diorite.

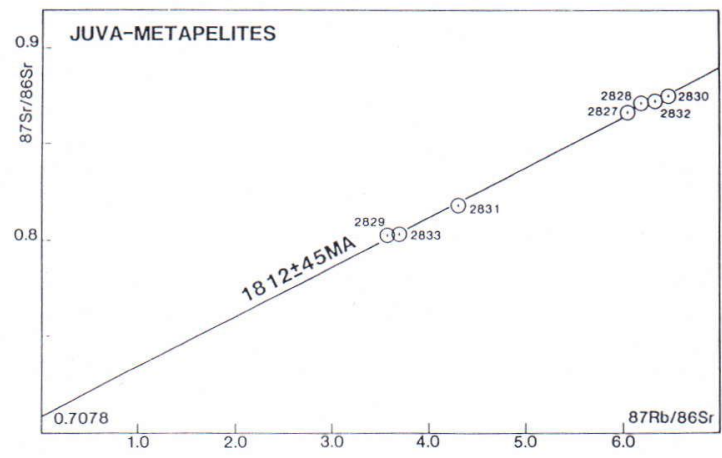

Fig. 13. Whole-rock isochron for the metapelitic rocks of the Juva zone. 
of Sulkava (Korsman et al. 1984). The ${ }^{87} \mathrm{Sr} /{ }^{86} \mathrm{Sr}$ initial value is only slightly higher than the value calculated for the metapelitic rocks of Pihtipudas.

\section{Data interpretation and comparison with existing ages}

Four distinct age groups have been found previously in the Pihtipudas-Iisalmi area: $1920 \mathrm{Ma}$ by U-Pb zircons dating, $1880 \mathrm{Ma}$ by U$\mathrm{Pb}$ zircon dating, 1860-1800Ma on monazites and sphenes and 1750-1650Ma on biotites (Fig. 14).

1920Ma on zircon have been reported on the quartz-diorite of Laajamäki (Vaasjoki and Sakko 1988). Similar ages were found from the Pyöreänsuonvuori granitoid (Vaasjoki and Sakko 1988) and the Rastinpää tonalitic gneiss (Kors- man et al. 1984). The results have been interpreted as the age of early synkinematic intrusions, a magmatic phase which is typical for eastcentral Finland.

$1880 \mathrm{Ma}$ on zircons has been widely found within the granitoid complex of central Finland (Aho 1979; H. Huhma 1986) as well as on granitoids of the Raahe-Ladoga schist belt (Neuvonen et al. 1981), being interpreted as the age of intrusion of synkinematic plutonic rocks. Ages of 1860 - 1840Ma on monazites and sphenes of the same geological units were interpreted representing the cooling after the main event of igneous activity (Hölttä 1988). Gorkov et al. (1970) measured $1872 \mathrm{Ma}$ on phyllitic schists and $1839 \mathrm{Ma}-$ $1818 \mathrm{Ma}$ on biotite schists by the $\mathrm{Rb}-\mathrm{Sr}$ whole rock method (recalculated with $\lambda^{87} \mathrm{Rb}=1.42 \mathrm{x}$ $10^{-11}$ ) giving an estimate of the time of metamorphism. An age of $1827 \mathrm{Ma}(\mathrm{Rb}-\mathrm{Sr}$ wholerock isochron) which he found on granitic veins

Table 3. Sample localities and isotopic data for the whole-rock analysis.

\begin{tabular}{|c|c|c|c|c|c|}
\hline $\begin{array}{l}\text { Sample } \\
\text { KAW No. }\end{array}$ & $\begin{array}{l}\text { Rb total } \\
\text { (ppm) }\end{array}$ & $\begin{array}{l}\text { Sr total } \\
\text { (ppm) }\end{array}$ & ${ }^{87} \mathrm{Rb} /{ }^{86} \mathrm{Sr}$ & ${ }^{87} \mathrm{Sr} /{ }^{86} \mathrm{Sr}$ & $\begin{array}{l}\text { Analytical } \\
\text { error }(1 \sigma)\end{array}$ \\
\hline \multicolumn{6}{|c|}{ Juva: Metapelite } \\
\hline 2827 & 242.76 & 117.88 & 6.05068 & 0.866168 & $0.0006^{\mathrm{b}}$ \\
\hline 2828 & 245.08 & 116.46 & 6.18614 & 0.871614 & $0.0010^{\mathrm{b}}$ \\
\hline 2829 & 152.48 & 124.35 & 3.58105 & 0.803474 & $0.0020^{\mathrm{b}}$ \\
\hline 2830 & 216.41 & 098.23 & 6.47828 & 0.874944 & $0.0007^{\mathrm{b}}$ \\
\hline 2831 & 234.98 & 159.24 & 4.31544 & 0.818152 & $0.0063^{b}$ \\
\hline 2832 & 213.07 & 098.73 & 6.34454 & 0.872241 & $0.0011^{\mathrm{b}}$ \\
\hline 2833 & 204.96 & 161.57 & 3.70458 & 0.803270 & $0.0005^{\mathrm{b}}$ \\
\hline \multicolumn{6}{|c|}{ Pihtipudas: Mica-Schist } \\
\hline 2839 & 145.64 & 216.77 & 1.95278 & 0.754685 & $0.000072^{\mathrm{a}}$ \\
\hline 2840 & 126.35 & 266.32 & 1.37714 & 0.741080 & $0.000058^{\mathrm{a}}$ \\
\hline 2841 & 115.89 & 338.19 & 0.993706 & 0.731012 & $0.000054^{\mathrm{a}}$ \\
\hline 2842 & 119.32 & 303.83 & 1.13848 & 0.735423 & $0.000059^{\mathrm{a}}$ \\
\hline 2843 & 136.29 & 253.12 & 1.56368 & 0.745836 & $0.000073^{\mathrm{a}}$ \\
\hline \multicolumn{6}{|c|}{ Laajamäki: Quartz-Diorite } \\
\hline 2844 & 42.712 & 203.45 & 0.608038 & 0.718191 & $0.000067^{\mathrm{a}}$ \\
\hline 2845 & 48.485 & 180.35 & 0.778979 & 0.722810 & $0.000056^{\mathrm{a}}$ \\
\hline 2846 & 64.273 & 227.64 & 0.818196 & 0.723950 & $0.000083^{\mathrm{a}}$ \\
\hline 2847 & 54.550 & 173.77 & 0.909891 & 0.726296 & $0.000060^{\mathrm{a}}$ \\
\hline 2848 & 51.338 & 173.52 & 0.857442 & 0.724963 & $0.000058^{\mathrm{a}}$ \\
\hline
\end{tabular}

a Relative standard deviation (sample measured on Avco mass spectrometer)

b $\%$ Standard error (sample measured on VG Sector mass spectrometer) 


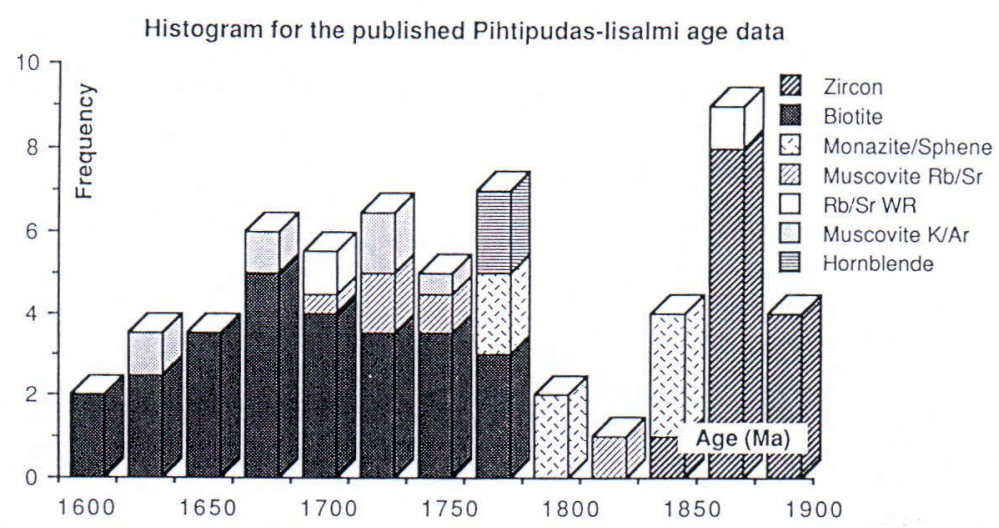

Fig. 14. Histogram for mineral and whole-rock ages of the Pihtipudas-Iisalmi area.

intruding Archean basement gneisses, testified the existence of a late kinematic magmatic phase. Similar ages were found by A.Huhma (1981) on dykes in North Karelia, dating zircons in a lamprophyre and sphene in microtonalite veins.

The age of the Svecokarelian metamorphism is still contradictory. Some hints are given for a 1880Ma metamorphic event in the Pielavesi area (Hölttä 1988). 1800Ma monazite and sphene ages of Pihtipudas on the other hand if interpreted as cooling ages have to date a cooling close to the metamorphic peak conditions or, if interpreted as formation ages date a $1800 \mathrm{Ma}$ event. Biotite (K-Ar) cooling ages in the Pielavesi block are as high as $1790 \mathrm{Ma}$, where in the other blocks the postmetamorphic cooling to $300^{\circ} \mathrm{C}$ can be dated with about $1750 \mathrm{Ma}-1650 \mathrm{Ma}$.

$1880 \mathrm{Ma}$ were measured on zircons of the tonalitic to granodioritic gneisses of Lampanjärvi, as well as on the Vaaraslahti hypersthene granite (Salli 1983, Vaasjoki and Sakko 1988). The Lampaanjärvi gneisses clearly represent a synkinematic intrusive rock foliated during metamorphism, showing at least two distinct lineations and elongated and oriented basic inclusions. The Vaaraslahti hypersthene granite in contrast does not show any orientation and resembles macroscopically a fresh intrusive rock, also microscopically a reaction texture can be seen: symplectitic quartz-biotite intergrowth replacing feldspar, polysynthetic twinning in plagioclase and myrmecitic intergrowth between feldspar and quartz are common. In the monzonitic variety symplectitic biotite intergrows with hornblende and pyroxene, hornblende often shows biotite margins or inclusions, sometimes being replaced by the mica completely.

Monazite $\mathrm{U}-\mathrm{Pb}$ dating on the intrusive yields a concordant age of $1874 \mathrm{Ma}$, the U-Pb zircon age is 1884 (Salli 1983) while the Rb-Sr whole rock isochron represents an age of $1805 \pm 5 \mathrm{Ma}$ (Haudenschild 1988a).

The whole-rock isochron age of $1875 \mathrm{Ma}$ of the Laajamäki quartz-diorite corresponds within the limit of the analytical error to the intrusion ages of the synkinematic tonalites. It also could represent an older metamorphic event described by Hölttä (1988), whilest its 1920Ma zircon age would represent the age of intrusion. The initial ${ }^{87} \mathrm{Sr} /{ }^{86} \mathrm{Sr}$ ratio of 0.7018 anyhow is too low to correspond with the strontium ratio of the original acid intrusive rock. ${ }^{87} \mathrm{Sr} /{ }^{86} \mathrm{Sr}$ ratios of about $0.703-0.705$ were reported for synkinematic intrusions of the Swedish Svecokarelides (Åberg 1978, Welin et al. 1980). Even on Archean gneisses of eastern Finland strontium ratios of 0.7023 0.7024 were measured (Martin et al. 1983). The low value calculated here can be explained only by the whole-rock system having been affected by an overprint, postdating the isochron age. 
Possible mechanisms for the lowering of the ${ }^{87} \mathrm{Sr} /{ }^{86} \mathrm{Sr}$ initial value are the following: Partial ${ }^{87} \mathrm{Sr}$ release, or a $\mathrm{Rb}(\mathrm{K})$ metasomatism adding $\mathrm{Rb}$ to the whole rock system. Loss of radiogenic strontium would result only in a minor shift of the initial strontium ratio due to the small amount of radiogenic strontium having been present at the time of the reset. Rubidium added to the system during a later hydrothermal event could lead to a shift of the isochron without seriously affecting the original isochron age (Gerstenberger 1989). The possibility of a rubidium (potassium) metasomatism in the area of Pielavesi has been mentioned previously (Hölttä 1988). Differences in the effect of metamorphism between the different whole-rock samples would result in a rotation of the isochron towards a higher age, the measured age therefore can be considered representing a maximum age for the original isochron. The question weather the $1875 \mathrm{Ma}$ ages does represent the age of a metamorphic overprint or only a meaningless age caused by a rotation of the isochron cannot be definitifely answered.

Fig. 15 gives the histogram for the published ages of the Joroinen-Sulkava area. The age groups defined are the same as in the area of Pihtipudas-Iisalmi, except for the lack of a 1920Ma phase. The type of rock (granulites of the Pielavesi block: see Hölttä 1988) related to that phase are absent in the Joroinen-Sulkava area. The whole rock isochron made on seven metapelite samples from the Juva zone (Fig. 3) defines an age of $1812 \pm 46 \mathrm{Ma}$. The initial ${ }^{87} \mathrm{Sr} /{ }^{86} \mathrm{Sr}$ ratio of 0.7077 corresponds well with the value found for the metapelites of Pihtipudas but also with the ratio given by Gorkov et al. (1970) for biotite-schists of Soviet Karelia. If we assume an oceanic ${ }^{87} \mathrm{Sr} /{ }^{86} \mathrm{Sr}$ ratio for the metapelitic rocks, the ratio of the ocean water during the time of sedimentation $(2000-2100 \mathrm{Ma})$ should have been somewhat lower than 0.707 . The age fits with the whole-rock ages measured by Gorkov et al. (1970) as well as the age calculated for the overprint of the Pihtipudas block.
An age of $1800 \mathrm{Ma}$ to $1820 \mathrm{Ma}$ is therefore proposed for a large scale metamorphic overprint of the Svecokarelic schist belt.

\section{Discussion}

\section{Pihtipudas-Iisalmi}

The highest age registered in the Pihtipudas block is the $1883 \mathrm{Ma}$ zircon age of synkinematic granitoids and metavolcanic rocks (Aho 1979). The metamorphic conditions close to the first occurrence of cordierite and andalusite in the metapelite refer to temperatures around $550^{\circ} \mathrm{C}$ at a pressure of about $3.5-3.8 \mathrm{~kb}$ (see: Hölttä 1988). Monazite and sphene of the same block yield concordant ages around 1800Ma (Aho 1979). The cooling to $500^{\circ} \mathrm{C}$ can be dated with the muscovite $\mathrm{Rb}-\mathrm{Sr}$ ages of $1732 \mathrm{Ma}$ and 1767Ma. Monazite and sphene ages therefore correspond to temperatures above $500^{\circ} \mathrm{C}$. $\mathrm{Rb}-\mathrm{Sr}$ (1732Ma/1767Ma) and K-Ar (1757Ma/1744Ma) muscovite ages show only minor differences refering to a rapid cooling between $1880 \mathrm{Ma}$ and $1750 \mathrm{Ma}$ decreasing after $1750 \mathrm{Ma}$ as can be seen by the $1699 \mathrm{Ma}$ and $1695 \mathrm{Ma} \mathrm{K}-\mathrm{Ar}$ biotite age results (Haudenschild 1988b) of the same sample. A schematic graph of the described cooling paths is given in Fig. 16.

The Korppinen-block has been described having had a metamorphic peak in the stability-field of sillimanite at $650-700^{\circ} \mathrm{C}$ and $5-6 \mathrm{~kb}$ (Hölttä 1988). A strong diaphthoretic overprint refers to a slow cooling or a later thermal overprint at intermediate temperatures. $\mathrm{Rb}$-Sr ages on muscovite (1708Ma/1733Ma) are remarkably lower than the K-Ar hornblende ages (1739Ma/1774Ma) of the same block. Together with the K-Ar muscovite (1695Ma/1690Ma) and biotite (1674/ $1694 \mathrm{Ma})$ ages, the age results refer to an approximately even slow cooling of the block for the time between the metamorphic peak and a cooling to $300^{\circ} \mathrm{C}$ (1670Ma). Differences between the $\mathrm{Rb}-\mathrm{Sr}$ muscovite ages of Pihtipudas and Korppinen can be explained by the Pihtipudas block 


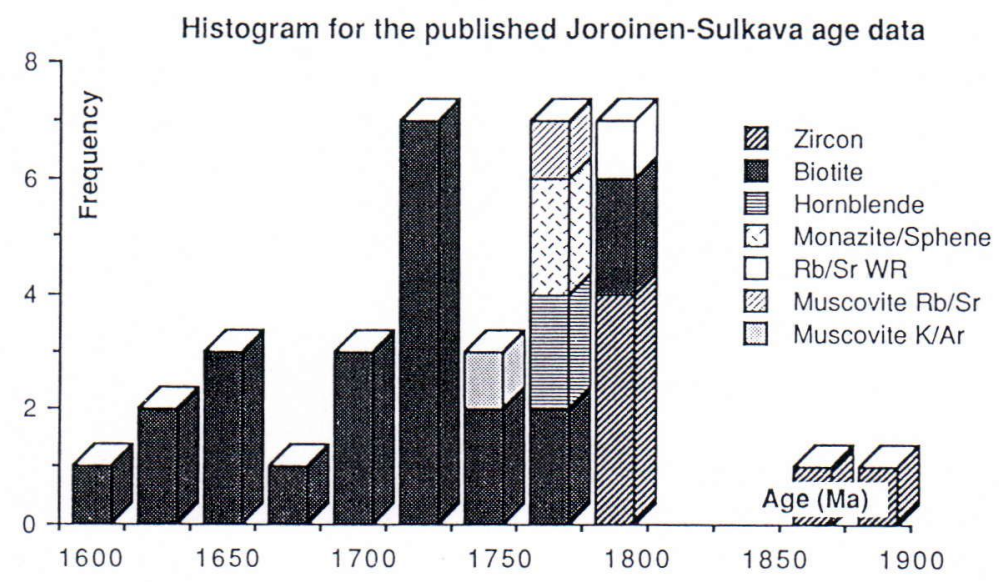

Fig. 15. Histogram for mineral and whole-rock ages of the Joroinen-Sulkava area.

having cooled to $500^{\circ} \mathrm{C}$ earlier. Both blocks can be shown to have passed the cooling to $300^{\circ} \mathrm{C}$ together (Haudenschild 1988b). The juxtaposition must have taken place at about $1700 \mathrm{Ma}$.

The Pielavesi block has been metamorphosed under granulite facies conditions at about $800^{\circ} \mathrm{C}$ and 5-6kb (Hölttä 1988). U-Pb zircon data of the Laajamäki quartz-diorite date the time of intrusion with about 1920Ma. An 1889Ma zircon age of a garnet-cordierite-orthopyroxene rock of Sahinperä (Vaasjoki and Sakko 1988) has been interpreted as the age of metamorphism (Hölttä 1988) corresponding with the whole-rock isochrone age of Laajamäki (1875Ma). Monazite ages of Sahinperä (Vaasjoki and Sakko 1988) and sphene ages of Mustikkamäki (Hölttä 1988) (all Pielavesi block) yield ages of $1873 \mathrm{Ma}$ and $1855-$ 1864Ma respectively, giving a hint to a fast cooling after an early (1880Ma) metamorphic phase. A later overprint of the whole-rock system can be assumed according to the disturbed wholerock isochron. Age and metamorphic conditions have not been evaluated; also, a 1820Ma metamorphic phase can be assumed. The temperature has certainly been below the monazite and also sphene closing temperature e.g. below about $550^{\circ} \mathrm{C}$; K-Ar biotite ages of $1750-1790 \mathrm{Ma}$ (Haudenschild 1988b) refer to a temperature somewhat above $300^{\circ} \mathrm{C}$.
The Lampaanjärvi block has to be seen in connection with the Vaaraslahti intrusion. The intrusion age has been dated with $1884 \mathrm{Ma}$ (U-Pb, zircon). A concordant 1874Ma monazite age corresponds with the monazite age of Sahinperä (see above) again indicating a rapid cooling after 1880Ma. K-Ar hornblendes of Syrjälä (Lampaanjärvi block) outside the contact metamorphic influence of Vaaraslahti yield ages of about $1770 \mathrm{Ma}$ where the corresponding muscovite ages are $1732 \mathrm{Ma} / 1751 \mathrm{Ma}(\mathrm{Rb}-\mathrm{Sr})$ and $1711 \mathrm{Ma} /$ $1750 \mathrm{Ma}$ (K-Ar). A metamorphic event postdating the intrusion-age therefore probably has exeeded the blocking temperature of hornblende.

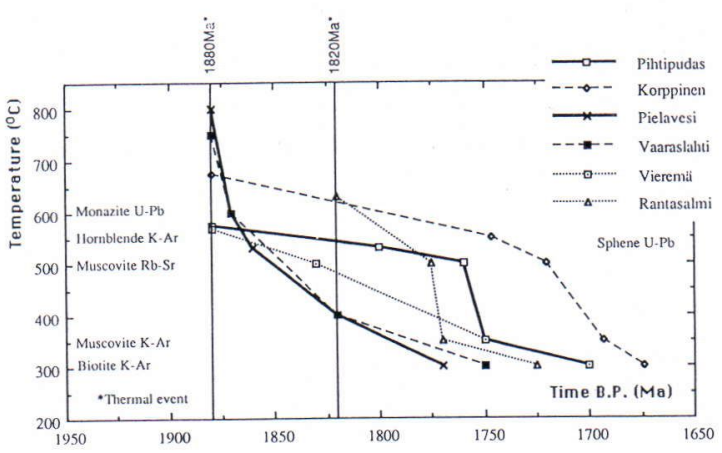

Fig. 16. Cooling history of the Pihtipudas, Korppinen, Pielavesi, Vaaraslahti, Vieremä and Rantasalmi area according to radiometric mineral ages. 
An overprint of the block around $1800 \mathrm{Ma}$ is indicated by a $1805 \mathrm{Ma} \mathrm{Rb}$-Sr whole-rock age of the Vaaraslahti intrusive (Haudenschild 1988a). KAr biotite cooling ages around the intrusive are as high as those of Pielavesi (1740Ma-1770Ma) where the corresponding biotite ages of the eastern part of the Lampaanjärvi block are considerably lower $(1620 \mathrm{Ma}-1680 \mathrm{Ma})$ referring to a later cooling to $300^{\circ} \mathrm{C}$ in the east than in the west.

Vieremä lies between the metavolcanic-metasedimentary complex of Kiuruvesi and the Archean basement of Iisalmi. The metamorphic conditions were described by Hölttä (1988) with $550-600^{\circ} \mathrm{C}$ and $4-5 \mathrm{~kb}$.

Hornblende K-Ar ages of 1995Ma-2143Ma indicate a partial reset of pre-Svecokarelian ages. The area is therefore thought to contain remnants probably of Jatulian age.

The high $\mathrm{Rb}-\mathrm{Sr}$ muscovite age refers to the existence of a metamorphic event prior to $1830 \mathrm{Ma}$. A reset at $1800 \mathrm{Ma}-1820 \mathrm{Ma}$ did not occur. KAr muscovite and biotite ages on the other hand equal those of Pihtipudas. A possible interpretation is a metamorphic overprint as described above around $1880 \mathrm{Ma}-1870 \mathrm{Ma}$ followed by a cooling below $500^{\circ} \mathrm{C}$. A second overprint around $1810 \mathrm{Ma}-1820 \mathrm{Ma}$ did not exceed $500^{\circ} \mathrm{C}$. The subsequent cooling is comparable to that of the Pihtipudas block $\left(350^{\circ} \mathrm{C}\right.$ at $1750 \mathrm{Ma}, 300^{\circ} \mathrm{C}$ at $1700 \mathrm{Ma})$. The higher hornblende K-Ar than muscovite $\mathrm{Rb}-\mathrm{Sr}$ ages can be seen as a hint to hornblende $\mathrm{K}$-Ar blocking- temperature exceeding $500^{\circ} \mathrm{C}$. If the indicated metamorphic temperatures are correct, hornblende under certain circumstances would retain argon even at temperatures of $550-600^{\circ} \mathrm{C}$.

\section{Joroinen-Sulkava}

The situation in the Joroinen-Sulkava area is somewhat easier and also indicative for the northern area. U-Pb zircon ages indicate magmatic activity at $1880 \mathrm{Ma}$ (Korsman et al. 1984) emplacing tonalitic to granodioritic rocks in the north- ern part of the area (Tuusmäki). The main metamorphic phase has been dated with zircons (Korsman et al. 1984; Vaasjoki and Sakko 1988) with about $1810 \mathrm{Ma}-1830 \mathrm{Ma}$. Detrital zircons show a linear increase in the reset (lead loss) from north to south yielding metamorphic ages only in the innermost area of the Sulkava thermal dome (Vaasjoki and Sakko 1988). The age of metamorphism has also been dated with $1812 \mathrm{Ma}$ by the $\mathrm{Rb}-\mathrm{Sr}$ whole-rock isochron in the northern Juvazone. The following cooling is registered by a $1796 \mathrm{Ma}$ monazite and a 1775 muscovite $\mathrm{Rb}-\mathrm{Sr}$ age. The late cooling to the blocking-temperature of biotite has occurred earlier in the north than in the south, the biotite ages decreasing from Rantasalmi to the Sulkava thermal dome from $1740 \mathrm{Ma}$ to $1600 \mathrm{Ma}$ (Haudenschild 1988b). An increase in the biotite ages can also be seen between Rantasalmi and Joroinen, referring to a possible fault system between the two zones (Haudenschild op. cit.).

\section{Conclusions}

Extensive age determination studies have been made in two different areas of the Raahe-Ladoga zone showing different evolutions of the north and the south.

Early Svecokarelian magmatic activity has been dated at $1920 \mathrm{Ma}$ and $1880 \mathrm{Ma}$. A metamorphic phase around $1880 \mathrm{Ma}-1870 \mathrm{Ma}$ can be recognized only in the Pihtipudas-Iisalmi area while it is absent in the Joroinen-Sulkava area. A large scale metamorphic event affected the whole zone at about 1820-1810Ma. The intensity of the overprint varies between different localities, gently in Pielavesi, Lampaanjärvi and Vieremä while reaching granulite facies conditions in the area of Sulkava. Cooling rates after the $1820 \mathrm{Ma}$ event can be calculated with $2-4^{\circ} \mathrm{C} / \mathrm{Ma}$ decreasing towards $1^{\circ} \mathrm{C} / \mathrm{Ma}$ between $1750 \mathrm{Ma}$ and $1700 \mathrm{Ma}$. The youngest biotite cooling ages registered are as low as $1600 \mathrm{Ma}$.

The $\mathrm{Rb}-\mathrm{Sr}$ muscovite ages measured in localities where monazite and sphene have been dated 
are always lower than the corresponding monazite and sphene ages. The blockingtemperatures of those minerals therefore are referred to temperatures above $500^{\circ} \mathrm{C}$.

Hornblende $\mathrm{K}$-Ar ages in the Vieremä block seem not to have been reset completely even at temperatures close to $600^{\circ} \mathrm{C}$. Their blockingtemperature therefore may be assumed being close to $600^{\circ} \mathrm{C}$. Different hornblende samples show argon loss at temperatures below their closing temperature possibly due to low temperature retrograde reactions.

Great care has to be taken in treating high age results as absolute numbers for effective $2 \sigma$ error of the age measurement being about $30 \mathrm{Ma}(2 \%)$. Histographicaly treated ages may provide information on the time of different events as age profiles comparing mineral ages dated with the same method may give information on the evolution of connected blocks and areas. Interpretation af absolute ages overlapping in their $2 \sigma$ error can give a hint to possible processes but never should be regarded as a final answer.

\section{References}

Åberg, G.A., 1978. Precambrian geochronology of southeastern Sweden. Geologiska Föreningens i Stockholm Förhandlingar, Vol 100.

Áberg, G.A. \& Persson, L., 1984. Radiometric dating of Precambrian rocks in Småland, southeastern Sweden. Geologisca Föreningens i Stockholm Förhandlingar 106, Pt., 319-325.

Aho, L., 1979. Petrogenetic and geochemical studies of metavolcanic rocks and associated granitoids in the Pihtipudas area, Central Finland. Geological Survey of Finland, Bulletin 300, 22 p.

Coleman, R.G. \& Lanphere, M.A., 1971. Distribution and age of high grade blueschist associated eclogites and amphibolites from Oregon and California. Geol. Soc. of America, Bulletin 82, 2397-2412.

Copeland, P.; Parrish, R.R. \& Harrison, T.M., 1988. Identification of inherited radiogenic $\mathrm{Pb}$ in monazite and its implications for U-Pb systematics. Nature 333, 760—763.

Dallmeyer, R.D. \& Rivers, T., 1983. Recognition of extraneous argon components through incremental release $40 \mathrm{Ar}-39 \mathrm{Ar}$ analysis of biotite and hornblende across the
Acknowledgements. This paper is the result of a cooperation between the Departement of Isotope Geology of the University of Berne and the Geological Survey of Finland. The laboratory work in Berne was supervised by Prof. Dr. E. Jäger, the field work by Dr. K. Korsman. I like to thank them both for their interest in this project and the help I got, in the field, in the lab and in the interpretation of the results, which I appreciate as being more than purely scientific. Prof. B. Giletti I like to thank for critically reading the manuscript and introducing me to new ideas.

Further I owe my thank to R. Brunner, who introduced me to mass-spectrometry, Mrs. I. Hebeisen and M. Giger for their help in the chem lab, U. Schaltegger and M. Soom for the potassium determinations and P. Hölttä and J. Eskelinen for their help in blasting and sampling in the field. Mrs. C. Hanny I owe my thank for the correction of the english manuscript.

Dr. M. Flisch helped me in measurement and interpretation. I would like to thank him and his wife Sibille for their friendship and help which added a lot to the success of my work.

This work has partly been supported by the Swiss National Science Foundation (Schweizerischer Nationalfonds) and the U.S. National Science Foundation Grant EAR-8720725 to B.J. Giletti.

Grenville metamorphic gradient in southwestern Labrador. Geochem. et Cosmochem. Acta 47, 413-428.

Dalrymple, G.B. \& Lanphere, M.A., 1969. Potassium argon dating. W.H. Freeman, San Francisco, 258 p.

Dodson, M.H., 1973. Closure temperature in cooling geochronological and petrological systems. Contib. Mineral. and Petrogr. 401, 259-274.

Dodson, M.H., 1986. Closure profiles in cooling systems. Material Science Forum, Vol 7, 145-154.

Farver, J.R. \& Giletti, B. J., 1989. Oxygen and strontium diffusion kinetics in apatite and their application to thermal history determinations. Contrib. min. geol. in press.

Flisch, M., 1982. Potassium-argon analysis; in: Numerical Stratigraphy (G.S.Odin ed.), John Wiley, Chichester. $151-158$.

Flisch, M., 1986. K-Ar dating of quaternary samples; in: Dating Young Sediments (Hurford. A., Jäger. E., Ten Cate, J.A.M. eds.), CCOP technical secretariat, Bankok, Thailand. 299-323.

Gaál, G. \& Rauhamäki, E., 1971. Petrological and structural analysis of the Haukivesi area between Varkaus and Savonlinna, Finland. Bulletin Geol. Soc. Finland 43-2, $265-337$. 
Gerstenberger, E., 1989. Autometasomatic Rb enrichments in highly evolved granites causing lowered $\mathrm{Rb}-\mathrm{Sr}$ isochron intercepts. Earth and Planetary Science Letters, 93, $65-75$.

Giletti, B.J. \& Farver, J. 1988. Thermal histories of rocks from $\mathrm{Rb}-\mathrm{Sr}$ mineral data and $\mathrm{Sr}$ diffusion kinetics. European assoc. of geochemistry, Internat. congress of geochemistry and cosmochemistry, Abstracts. Chemical Geology, 70, 1/2, p. 183.

Gorkov, I.M.; Varshavskaja, E.S.; Kutyavin, E.P. \& LobachZuchenko, S.B., 1970. Preliminary Rb-Sr geochronology of the northern Ladoga region, Soviet Karelia, Eclogae Geol. Helveticae 63/1, 95-104.

Hanson, G.N. \& Gast, P.W., 1967. Kinetic studies in contact metamorphic zone. Geochem. et Cosmochem. Acta 31, 1119-1153.

Härme, M., 1961. On the fault lines in Finland. Suomen geologisen seuran julkaisuja. XXXIII, 75-vuotisjuhla julkaisu, Bulletin soc. geol. Finlande 196, 437-444.

Harper, C.T,. 1967. The geological interpretation of potassium-argon ages of metamorphic rocks from the Scottish Caledonides. Scot. J. Geol. 3, 46-66.

Harper, C.T,. 1970. Graphical solution to the problem of radiogenic Ar-40 loss for metamorphic minerals. Eclogae Geol. Helveticae 63/1, 119-140.

Harrison, T.M., 1981. Diffusion of 40Ar in hornblende: an application for reconstructing thermal histories. The Geol. Soc. of America, 94th annual meeting, Abstracts with programs, 13, 7, p. 468.

Harrison, T.M., 1986. Exsolution in hornblende and its consequences for $40 \mathrm{Ar}-39 \mathrm{Ar}$ age spectra and closure temperature. Geochem. et Cosmochem. Acta. 50, 247-253.

Hart, S.R,. 1964. The petrology and isotopic mineral-age relations of a contact zone in the Front Range, Colorado, J. Geol. 72, 493-525.

Haudenschild, U., 1988a. Metamorphism and uplift history of the Svecokarelides in the areas of Pihtipudas-Iisalmi and Joroinen-Sulkava. PhD thesis, University of Bern, Switzerland, unpublished.

Haudenschild, U., 1988b. K-Ar age determination on biotite and muscovite in the Pihtipudas-Iisalmi and Joroinen-Sulkava areas, eastern Finland. Geological Survey of Finland, Bulletin 343, 33-50.

Hölttä, P., 1988. Metamorphic zones and the evolution of granulite grade metamorphism in the early Proterozoic Pielavesi area, central Finland. Geological Survey of Finland, Bulletin 344, $50 \mathrm{p}$.

Huhma, A., 1981. Youngest precambrian dyke rocks in north Karelia, East Finland. Bulletin Geol. Soc. Finland 53, 2, $67-82$.

Huhma, H., 1986. Sm-Nd, U-Pb and $\mathrm{Pb}-\mathrm{Pb}$ isotopic evidence for the origin of the Early Proterozoic Svecokarelian crust in Finland. Geological Survey of Finland, Bulletin 337, $48 \mathrm{p}$.
Jäger, E, . 1977. Introduction to geochronology; in: Lectures of isotope geology (Jäger, E., Hunziker, J., eds.), Springer Verlag, Heidelberg, 1-12.

Kirsten, T., 1966. Determination of radiogenic argon; in: Potassium argon dating (Schaeffer, O.A., Zähringer, J., eds.), Springer Verlag, Heidelberg, 7-39.

Korsman, K., 1977. Progressive metamorphism of the metapelites in the Rantasalmi-Sulkava area, southeastern Finland. Geological Survey of Finland, Bulletin 290, 82 p.

Korsman, K, . 1988. Tectono-metamorphic evolution of the Raahe-Ladoga zone; Introduction. Geological Survey of Finland, Bulletin 343, 3-6.

Korsman, K.; Hölttä, P.; Hautala, T. \& Wasenius, P., 1984. Metamorphism as an indicator of evolution and structure of the crust in eastern Finland. Geological Survey of Finland, Bulletin 328, 40 p.

Lehtovaara, J., 1972. Apatite fission track dating of Finnish Precambrian intrusives. Annales Academiae Scientiarium Fennicae, Series A, III Geologica-Geographica, 117, 94 p.

Martin, H.; Chauvel, C.; Jahn, B.M. \& Vidal P., 1983. Rb$\mathrm{Sr}$ and $\mathrm{Sm}-\mathrm{Nd}$ ages and isotopic geochemistry of Archean granodiorite gneisses from eastern Finland. Precambrian Res. 20, 79-91.

Marttila, E., 1976. Evolution of the Precambrian volcanic complex in the Kiuruvesi aera, Finland. Geological Survey of Finland, Bulletin 283, 109 p.

Mattinson, J.M., 1978; Age, origin, and thermal histories of some plutonic rocks from the Salinian Block of California. Contrib. Mineral. Petrol. 67, 233-245.

Mattinson, J.M., 1982. U-Pb blocking temperatures and $\mathrm{Pb}$ loss characteristics in young zircon, sphene and apatite. The Geol. Soc. of America. 95th annual meeting. Abstracts with programs, vol. 14.

McDowell, F.W.; Lehman, D.H.; Gucwa, P.R.; Fritz, D. \& Maxwell, J.C., 1984. Glaucophane schists and ophiolites of the northern California Cost Ranges: Isotopic ages and their tectonic inplications. Geol. Soc. of America, Bulletin 95, 1373-1382.

Neuvonen, K.J.; Korsman, K.; Kouvo, O. \& Paavola, J., 1981. Paleomagmatism and age relations of the rocks in the main sulphide ore belt in central Finland. Bulletin Geol Soc. Finland 53-2, 109-133.

Onstott, T.C. \& Peacock, M.W., 1987. Argon retentivity of hornblendes: a field experiment in a slowly cooled metamorphic terrane. Geochem. et Cosmochem. Acta 51, 2891-2903.

Paavola, J., 1976. On the metamorphism of the Haukivesi area. Bulletin Geol. Soc. Finland, 48-1, 1-3.

Paavola, J., 1986. A communication on the U-Pb and K-Ar age relations of the Archean basement in the LapinlahtiVarpaisjärvi area, central Finland. Geological Survey of Finalnd, Bulletin 339, 7-15.

Pajunen, M, . 1988. Deformation analysis of cataclastic struc- 
tures and faults in the Tervo area, central Finland. Geological Survey of Finland, Bulletin 339, 16-31.

Salli, I., 1983. Pielaveden karta-alueen kallioperä. Kallioperän selitykset, Lehti 3314 Pielavesi.

Schumacher, E., 1975. Herstellung von $>99.9997$ per cent $38 \mathrm{Ar}$ für die 40K/40Ar Geochronologie, Chimia 29, $441-442$.

Steiger, R.H. \& Jäger, E., 1977. Subcomission on geochronology: convention on the use of decay constants in geoand cosmochronology. Earth and Planetary Sci. Letters 36, 359-362.

Vaasjoki, M. \& Sakko, M., 1988. The evolution of the Raahe-Ladoga zone in Finland: Isotopic constraints. Geological Survey of Finland, Bulletin 343, 7-32.
Wagner, G.A.; Reimer, G., M. \& .Jäger, E., 1977. Cooling ages derived by apatite fission-track, mica $\mathrm{Rb}-\mathrm{Sr}$ and $\mathrm{K}$ Ar dating: the uplift and cooling history of the central alps. Memoire degli Instituti di Geologia e Mineralogia dellUniversita di Padova, Vol. XXX, 27 p.

Welin, E.; Kähr, A.M. \& Lundegårdh, P.H., 1980. Rb-Sr isotope systematics at amphibolite facies conditions, Uppsala region, eastern Sweden. Precambrian Res. 13, $87-101$.

Received September 8, 1989

Revision accepted December 20, 1989 